\title{
PLEOMORPHIC ADENOMA OF THE PALPEBRA: A HISTOPATHOLOGICAL CASE REPORT
}

\author{
Ina Kobakova ${ }^{1}$, Hristo Popov', Ekaterina Softova ${ }^{2}$, Snezhana Spasova ${ }^{1}$, George St. Stoyanov $^{1}$ \\ ${ }^{1}$ Department of General and Clinical Pathology, Forensic Medicine and Deontology, \\ Faculty of Medicine, Medical University of Varna, Bulgaria \\ ${ }^{2}$ Individual Medical Diagnostic Laboratory/IMDL/City Lab, Varna, Bulgaria
}

\begin{abstract}
Pleomorphic adenoma (PA) is a benign glandular tumor, originating most commonly from the parotid gland. Other rare locations for PA are the breast, lung, lacrimal glands, etc. PA originating from other exocrine glands such as the glands of Moll in the palpebra are extremely rare. Herein we report a case report of a 66-year-old female patient with such PA, excised due to vision impediment, with a discussion on the histological aspects and diagnostic and management approaches of PA in this rare location.
\end{abstract}

Keywords: pleomorphic adenoma, palpebral, pathology, glands of Moll

\section{INTRODUCTION}

Pleomorphic adenoma (PA), also referred to as a mixed tumor (lat. tumor mixtus), is a benign neoplasia of myoepithelial and glandular epithelial origin. $\mathrm{PA}$ is the most common salivary gland tumor, constituting up to two-thirds of all salivary gland neoplasms (1). Other organ locations for PA such as lung, lacrimal gland, and breast are extremely rare (2).

Development from the exocrine glands of the skin is an extremely casuistic site of origin for PA (3). One such casuistic site is the development of PA from

Address for correspondence:

George St. Stoyanov

Faculty of Medicine

Medical University of Varna

55 Marin Drinov St

9002 Varna

e-mail:georgi.geesh@gmail.com

Received: August 9, 2021

Accepted: September 2, 2021 the apocrine glands of Moll, located in the palpebral margin. Whilst this is part of the group of orbital PA, the majority of these entities are due to PA developing from the lacrimal gland, hence rendering palpebral PA a rare entity in human pathology.

Herein we present a case of a 66-year-old female with a PA originating from the apocrine gland of Moll.

\section{CASE PRESENTATION}

The patient presented to an outpatient ophthalmology clinic with a mass in the medio-inferior aspect of the palpebra of the right eye, measuring $9 \mathrm{~mm}$ by $5 \mathrm{~mm}$, that had slowly been growing over the past several months. On palpation, the mass was firm and well-demarcated from the surrounding edematous palpebral tissues.

The patient reported no prior trauma to the area and no pain from the lesion. No family history of an ocular tumor could be reported by the patient. Regional lymph nomes showed no palpable changes. Previous medical history was relatively unevent- 
ful, with mild hypertension under adequate medication control.

Due to the mass severely impeding the vision of the patient, a surgical procedure for the enucleation of the tumor was elected.

Due to the site of the lesion, preoperative biopsies, both cytological in the form of fine-needle aspiration biopsy (FNAB) and histological through cut biopsy, were considered but were deemed too risky due to the firmness of the mass. Therefore, surgery was elected without prior histological verification.

Surgery was performed under local anesthesia, with cold steel instruments, with a total surgical time of 30 minutes and minimal intraoperative bleeding. Cosmetic sutures were applied to the surgical site, with good cosmetic results. The patient was discharged within the same day and on follow-up reported no complications, the surgical site edema had disappeared within three days, with no hematoma, seroma, or infection occurring locally. Sutures were removed on the tenth day after the operation.

The specimen obtained from the surgical intervention was sent for histopathological evaluation and fixated for 24 hours in 10\% buffered formalin solution. The formalin-fixed tissues were embedded in paraffin and cut into 6 micrometer thick slides, stained with hematoxylin and eosin for pathomorphological evaluation.

Grossly on cross-section, the tumor revealed a diffuse pale yellow color and a firm, homogenous cut surface.

Histologically the specimen was well demarcated from the surrounding tissue by a fibrous pseudocapsule and it showed a relatively asymmetrical architecture (Fig. 1A). At higher magnification, multiple pleomorphic areas of admixed tubular structures and stromal components with different components were seen in the specimen.

The predominant areas were epithelial ductal proliferations amidst a myxoid stroma with focal areas of hyalinization (Fig. 1B). Other scanter areas of the specimen showed squamous cell metaplasia with some abundant extracellular keratin deposits akin to keratin cysts, focal depositions of calcium, and stromal areas of chondroid metaplasia (Fig. 1B and 1C). The surgical excision was noted to be complete, with-

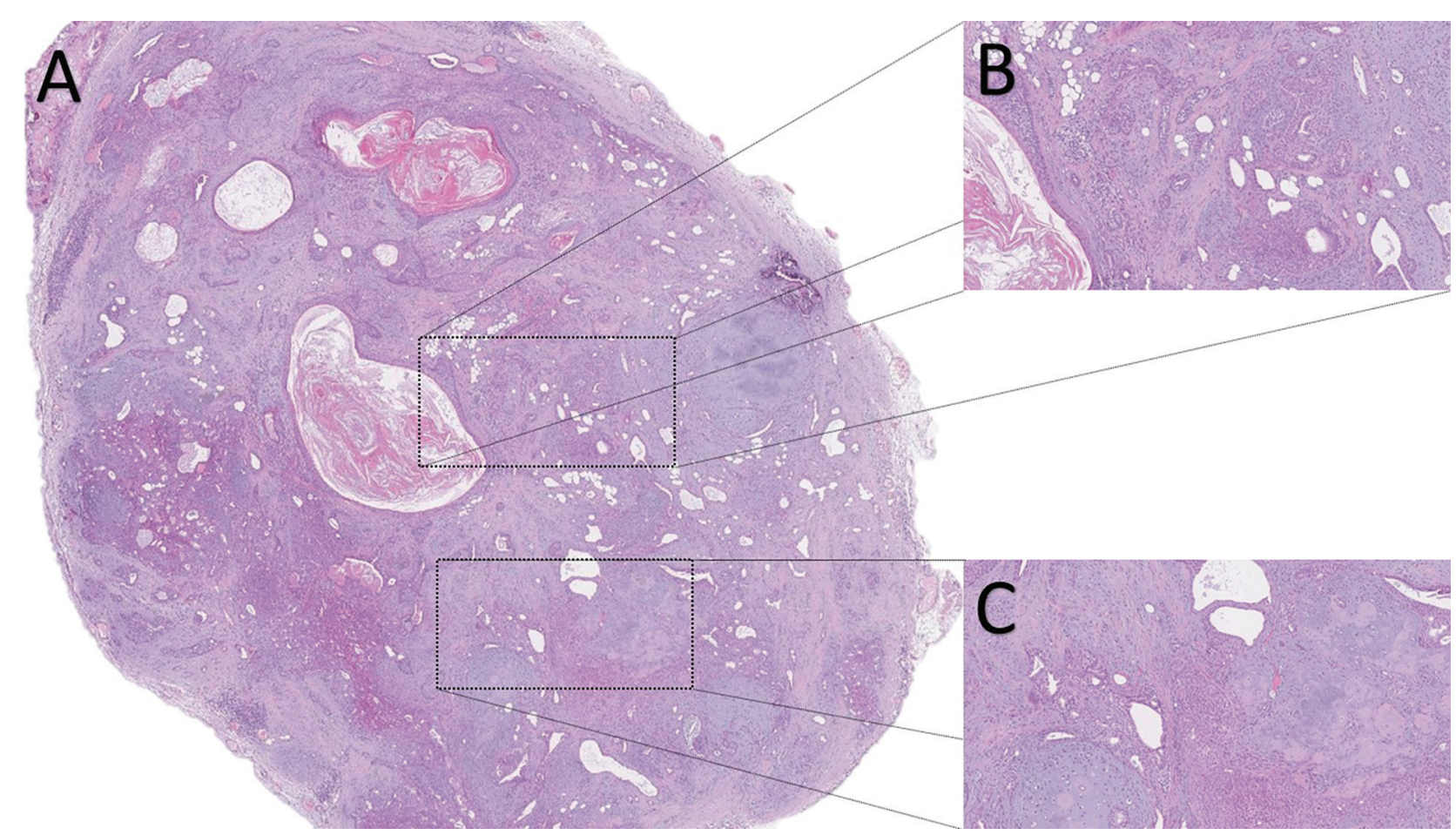

Fig. 1. Specimen sent for histopathology. A: macro slide view, hematoxylin and eosin staining; B: areas with ductal proliferation and squamous cell metaplasia, original magnification 100x, hematoxylin and eosin stain; $\mathbf{C}$ : areas with chondroid metaplasia, original magnification 100x, hematoxylin and eosin stain. 
Table 1. Tumors of the eyelids, adapted from Sternberg, 2016 (7)

\begin{tabular}{|c|c|}
\hline $\begin{array}{l}\text { Benign } \\
\text { neoplasia }\end{array}$ & $\begin{array}{l}\text { Epithelial: } \\
\text { Squamous cell papilloma } \\
\text { Keratoacanthoma } \\
\text { Seborrheic keratosis } \\
\text { Inverted follicular keratosis } \\
\text { Melanocytic: } \\
\text { Nevocellular nevi } \\
\text { Vascular: } \\
\text { Capillary/cavernous haemangioma } \\
\text { Lymphangioma } \\
\text { Glomus tumor } \\
\text { Adnexal: } \\
\text { Apocrine gland adenoma } \\
\text { Eccrine acrospiroma } \\
\text { Oncocytoma } \\
\text { Pilomatrixoma } \\
\text { Pleomorphic adenoma } \\
\text { Syringoma } \\
\text { Trichoepithelioma } \\
\text { Trichofolliculoma } \\
\text { Trichilemmoma } \\
\text { Developmental: } \\
\text { Phakomatous choristoma } \\
\text { Cysts: } \\
\text { Dermoid cyst } \\
\text { Epidermal inclusion cyst } \\
\text { Sudoriferous cysts } \\
\text { Mesenchymal tumors } \\
\text { Fibrous histiocytoma } \\
\text { Xanthelasma } \\
\text { Miscellaneous: } \\
\text { Granular cell tumor }\end{array}$ \\
\hline $\begin{array}{l}\text { Malignant } \\
\text { neoplasia }\end{array}$ & $\begin{array}{l}\text { Epithelial carcinoma: } \\
\text { Basal cell } \\
\text { Sebaceous cell } \\
\text { Squamous cell } \\
\text { Melanocytic: } \\
\text { Melanoma } \\
\text { Vascular: } \\
\text { Angiosarcoma } \\
\text { Adnexal carcinoma: } \\
\text { Apocrine/eccrine sweat/ } \\
\text { mucinous gland carcinoma } \\
\text { Miscellaneous: } \\
\text { Mycosis fungoides } \\
\text { Merkel cell tumor } \\
\text { Metastatic tumors }\end{array}$ \\
\hline
\end{tabular}

out any microsatellites noted. However, due to the specifics of the site and the enucleation of the tumor with minimal remaining healthy surrounding tissue, the presence of microsatellites could not be excluded based on the tight resection margins of the specimen.

Two and a half years following the surgical intervention the patient is still regular to follow-up and no local recurrence has been noted. The surgical site has completely healed with perfect esthetic results and no excessive scar tissue formation. The palpebral function has been fully restored and the patient has not reported any functional deviations of the palpebra.

\section{DISCUSSION}

The revised fourth edition of the World Health Organization (WHO) Classification of Tumors of the Head and Neck defines PA as a well-defined tumor characterized by its pleomorphic or mixed appearance (4). There is wide intermixing of the recognizable epithelial component with mucoid, myxoid, and chondroid components. Although the lesion presents several distinct histological features due to the different compositions of the extracellular matrix, it is generally considered to be a benign neoplasm.

The exact etiology is obscure although the incidence increases from 15-20 years after radiation exposure. A few studies have suggested an association of the tumor with simian virus 40 (SV 40).

Whilst PA in the orbital area is common, the majority of the tumors are located in the lacrimal gland, with the palpebral location being extremely rare $(5,6)$.

These rare tumors most often originate from the glands of Moll-apocrine glands located in the anteroinferior aspect of the palpebra (Table 1).

Histologically PA of the palpebra adheres to the histological features of PA in other locations as well as their general clinical aspects of high recurrence probability and potential for malignant transformation (8). The histological features include a mixed proliferation of polygonal epithelial and spindle-shaped myoepithelial cells in a variable stroma matrix with mucoid, myxoid, cartilaginous, or hyaline change. The epithelial elements form duct-like structures, sheets, clumps, or interlacing strands. The ducts and tubules are usually seen exhibiting an 
Ina Kobakova, Hristo Popov, Ekaterina Softova et al.

outer lining in addition to an inner cuboidal epithelial cell layer. This considered outer myoepithelial cell layer (or layers) merges into the surrounding stroma which also contains dispersed or clumped myoepithelial element cells. Areas of squamous metaplasia and epithelial pearls can also be present, as in our case. The tumor lacks a true capsule and is surrounded by a fibrous pseudocapsule of variable thickness (9). In many cases, there are also extensions of the tumor in the adjacent tissue in the form of microsatellites, which are difficult to note grossly and, if the excision is not complete, can give rise to local recurrence of the PA $(9,10)$.

Both cytological (fine-needle aspiration), with a diagnostic sensitivity of around $90 \%$, and histological (excision) biopsies, with a diagnostic sensitivity of around 97\%, are diagnostic for this entity, however, due to the site of origin, an excision approach is preferred. An added pro for excision biopsy is better quality immunostaining-immunohistochemistry is needed to distinguish from other entities or a malignantly transformed PA (11).

\section{CONCLUSION}

PA of the palpebra is a rare entity. Grossly, the differential diagnosis of the condition is wide, with such conditions as anterior orbital or lid dermoid cyst, lacrimal gland duct cyst (dacryops), benign and malignant intrinsic lacrimal gland tumors, lymphoid and inflammatory lesions, or even a large chalazion. Nevertheless, the diagnosis is histopathological after excision of the tumor.

\section{REFERENCES}

1. Califano J, Eisele DW. Benign salivary gland neoplasms. Otolaryngol Clin North Am. 1999; 32(5):861-73. doi: 10.1016/S0030-6665(05)70178-X.

2. Jain S, Hasan S, Vyas N, Shah N, Dalal S. Pleomorphic adenoma of the parotid gland: Report of a case with review of literature. Ethiop J Health Sci. 2015; 25(2):189-94. doi: 10.4314/ejhs.v25i2.13.
3. Rothwell R, Campelos S, Prazeres S. Pleomorphic adenoma of the eyelid with apocrine gland origin; an atypical location. J Ophthalmic Vis Res. 2016; 11(4):439-41. doi: 10.4103/2008-322X.194144.

4. El-Naggar A, Chan J, Grandis J, Takata T, Slootweg P, editors. WHO Classfication of Head and Neck Tumours. 4th ed.; 2017.

5. Vangveeravong S, Katz SE, Rootman J, White V. Tumors arising in the palpebral lobe of the lacrimal gland. Ophthalmology. 1996; 103(10):1606-12. doi: 10.1016/S0161-6420(96)30456-9.

6. Harrison W, Pittman P, Cummings T. Pleomorphic adenoma of the lacrimal gland: A review with updates on malignant transformation and molecular genetics. Saudi J Ophthalmol. 2018; 32(1):13-6. doi: 10.1016/j.sjopt.2018.02.014.

7. Mills S, editor. Sternberg's Diagnostic Surgical Pathology. 6th ed. Wolters Kluwer; 2016.

8. Gleave EN, Whittaker JS, Nicholson A. Salivary tumours-experience over thirty years. Clin Otolaryngol Allied Sci. 1979; 4(4):247-57. doi: 10.1111/ j.1365-2273.1979.tb01897.x.

9. Infante-Cossio P, Gonzalez-Cardero E, Garcia-Perla-Garcia A, Montes-Latorre E, Gutierrez-Perez JL, Prats-Golczer VE. Complications after superficial parotidectomy for pleomorphic adenoma. Med Oral Patol Oral Cir Bucal. 2018; 23(4):e485-92. doi: 10.4317/medoral.22386.

10. Kato H, Kawaguchi M, Ando T, Mizuta K, Aoki M, Matsuo M. Pleomorphic adenoma of salivary glands: common and uncommon CT and MR imaging features. Jpn J Radiol. 2018; 36(8):463-71. doi: 10.1007/s11604-018-0747-y.

11. Shalley S, Chand N, Aggarwal A, Garg LN, Yadav V, Yadav A. Diagnostic accuracy of fine needle aspiration cytology in lesions of oral cavity and salivary glands: A clinico-pathological study. Open Dent J. 2018; 12:782-90. doi: 10.2174/1745017901814010782. 